\title{
LATE HOLOCENE CHANGES IN VEGETATION OF THE MRĄGOWO LAKELAND (NE POLAND) AS REGISTERED IN THE POLLEN RECORD FROM LAKE SALĘT
}

\author{
Marta Szal $^{1}$, Mirosława Kupryjanowicz ${ }^{1}$, Mariusz Wyczółkowski ${ }^{2}$ \\ ${ }^{1}$ Institute of Biology, University of Biatystok, Świerkowa 20b, 15-950 Biatystok, Poland; \\ e-mail:martaszal@op.pl,m.kupryjanowicz@uwb.edu.pl \\ ${ }^{2}$ Wojciech Kętrzyński Museum, Plac Zamkowy 1,11-400 Kętrzyn, Poland; e-mail: mw@muzeum.ketrzyn.pl
}

\begin{abstract}
Pollen analysis of sediments from the upper part of bottom deposits from Lake Salęt allowed reconstruction of main stages of the Late Holocene vegetation transformation in the Mragowo Lake District (from ca. 3600 cal. years BC) and to correlate some of these changes with immigration and economic activity of local human groups. Significant spreading of secondary semi-natural birch forest, development of hornbeam forest and increasing importance of anthropogenic open communities were the most characteristic features of vegetation evolution. A definite breakdown of elm took place between 2900 and 2500 cal. years BC, slightly after increased contribution of birch in woodlands. Disappearance of hazel around 1200 cal. years BC, accompanied by expansion of hornbeam has been observed and should be linked with activity of the Ząbie-Szestno type culture and the Lusatian culture tribes during the Bronze Age, but not with a climate change. Considerable intensification of settlement processes recorded in the younger part of the Subatlantic chronozone was one of the important reasons that were responsible for quick changes in forest structure. Strong and continued deforestation started as early as the end of the $10^{\text {th }}$ century AD and was substantially intensified in the first half of the $13^{\text {th }}$ century.
\end{abstract}

Key words: vegetation transformations, Late Holocene, pollen analysis, Mrągowo Lake District, Masuria, NE Poland.

Manuscript received 28 October 2013, accepted 14 May 2014

\section{INTRODUCTION}

Pollen analysis is one of the most widely used research tools in paleoecology that helps in detecting responses of natural vegetation to human impacts through history, as well as to climate and environmental change on a variety of temporal and spatial scales (e.g. Prentice, 1988; Huntley, 1990). Pollen records have been used to study biostratigraphy, vegetation patterns and agrarian history of the Masurian Lakeland for many years. Among the sites that have been palynologically examined within modern standards, only a few included pollen sequences covering the Subatlantic chronozone. These were pollen sequences from: Lake Mikołajskie (Ralska-Jasiewiczowa, 1966), Lakes Kruklin, Mamry and Tałty (Stasiak, 1967, 1971), Lake Dgał Wielki (FilbrandtCzaja, 2000), Lakes Miłkowskie, Wojnowo and Łazduny, former Lake Staświńskie and the Szczepanki site (Wacnik, 2009a, b; Wacnik et al., 2012a), Wielkie Błoto mire (Karpińska-Kołaczek et al., 2013) and Skaliski Forest (Kołaczek et al., 2013). However, beyond the profiles described by Wacnik (2009a, b; Wacnik et al., 2012a) most studied sequences were poorly supported by radiocarbon dating, or the ages were missing. This fact restricted possible reconstruction of rate of environmental changes and their correlation with archaeological, historical and climatic data.
From a paleoecological perspective northeastern Poland is an interesting region, because it is under influence of a transitional climate (e.g. Woś 1999). Occurrences of different air masses have wide range of influence upon natural distributions of plants typical for both the maritime (e.g. Cladium mariscus and Juncus subnodulosus) and the boreal climate (among others: Polemonium caeruleum, Nymphaea candida and Nuphar pumila; Gałka et al., 2014). Such specific character of this part of Poland is reflected also in geobotanical division of the country, in which it was included in the Masuria-Belarus North Divide (Matuszkiewicz 2008). Palaeoecological research in this area is a key to understanding of mechanisms and reasons for plant migration (Kupryjanowicz 2008; Lamentowicz et al., 2008). To assess, to what extent the records from maritime and more continental regions are different from one another, more research and especially multi-proxy investigation is needed.

Archaeologists have already demonstrated a specific and unique character of economic activity in northeastern Poland in relation to central Europe (e.g. Okulicz 1973; Karczewski 2011). A particular feature of this area was a prolonged existence of foraging and a very late acceptance of farming as the basis for food procurement, in contrary to the rest of Poland (Wacnik et al., 2012a). 


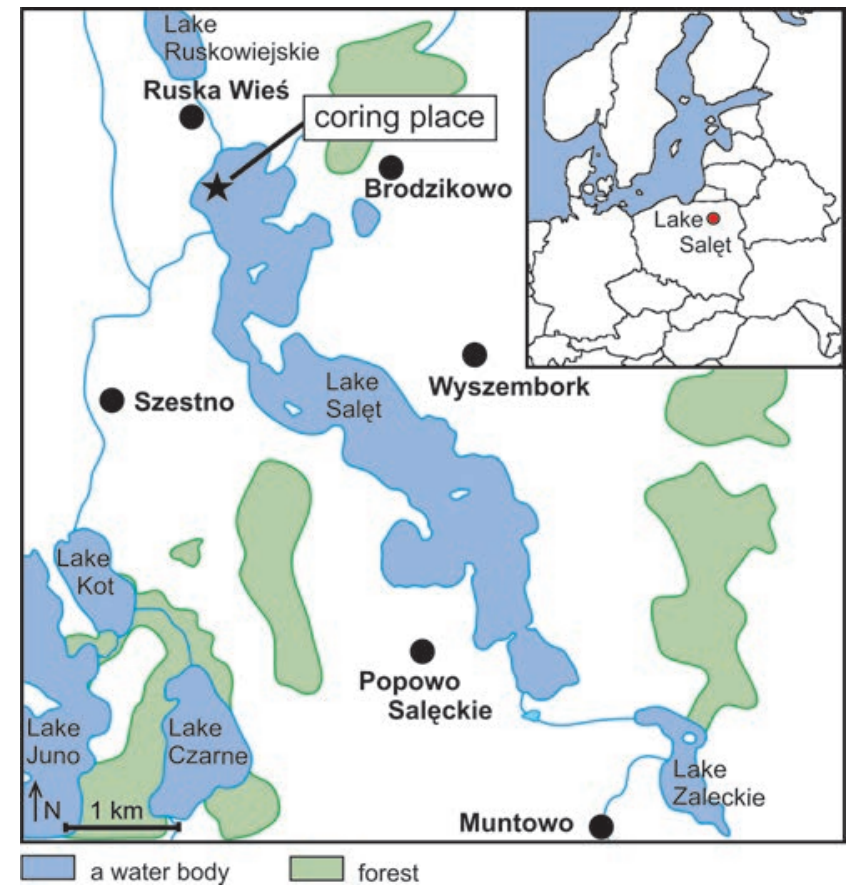

Fig. 1. Location of Lake Salęt and coring site.

This study is focused on reconstruction of the Late Holocene vegetation changes in the Mragowo Lake District, based on pollen analysis and supported by AMS radiocarbon dating. The primary aim was to present vegetation development in the surroundings of Lake Salęt from ca. 3600 cal. years BC and to provide data for evaluation of woodland transformation by a man.

\section{MATERIAL AND METHODS}

\section{Description of the study site}

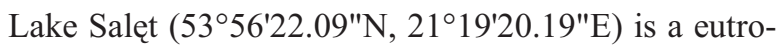
phic water body with area of 327.7 hectares (Jańczak, 1999). It is located between the villages Szestno, Ruska Wieś, Brodzikowo and Wyszembork in the centre of the Mragowo Lake District, which is a part of the Masurian Lake District in northeastern Poland (Fig. 1).
The lake is of glacial origin and is located in a depression surrounded by morainic hills. Steep escarpments, over $10 \mathrm{~m}$ high, slope down to the water surface on both eastern and western lakesides; whereas northern and southern slopes are more gentle. The lake is divided into two parts - the smaller, northern part is named Lake Salęt Mały and the larger southern part is Lake Salęt Wielki (Fig. 1). Maximum water depth is $17.2 \mathrm{~m}$ and mean depth is $4.9 \mathrm{~m}$ (Jańczak, 1999). The lake is fed by a single stream and in addition to surface runoff, an inflow of shallow underground water from the surrounding moraine upland is probably also possible.

The vegetation around Lake Salęt is almost devoid of forest and indicates substantial anthropogenic changes. The forest occurs in $10 \%$ of the area only whereas most is occupied by grasslands: meadows and pastures $30 \%$, arable land of $60 \%$. A land strip of $500 \mathrm{~m}$ around the lake is overgrown by herbaceous vegetation, with scattered trees occurring near buildings, along roads and streams and at the lakeshore only.

\section{Coring and dating}

In winter 2010 a core of sediments was taken from the frozen surface of Lake Salęt with the use of the Więckowski's piston corer and the Kajak gravity corer. Coring was performed close to the deepest part of the lake (water depth $15 \mathrm{~m}$ ), with bottom deposits $15.70 \mathrm{~m}$ thick (Fig. 1). The present paper deals with a top part of the log only (depth to $10.80 \mathrm{~m}$ ). This part of the core is composed of calcareous gyttja, rich in organic matter and relatively poor in sand, clay and silt.

AMS radiocarbon dating of seven pollen concentrate samples was performed in the Gliwice Absolute Dating Methods Centre (Table 1). The isolation of pollen concentrates from the sediment was performed by removal of calcium carbonate using 38\% $\mathrm{HCl}$ and humic acids, using $10 \%$ $\mathrm{KOH}$ and $2-4 \mathrm{~cm}^{2}$ of sediment was used for this purpose.

Short-lived radionuclides ${ }^{210} \mathrm{~Pb}$ were measured in the uppermost layer, $30 \mathrm{~cm}$ thick. The analysis was carried out in the Institute of Geological Sciences of the Polish Academy of Sciences in Warsaw.

AMS radiocarbon dating of sediments from Lake Salęt

Table 1

\begin{tabular}{|c|c|c|c|c|c|}
\hline No. & Depth $(\mathrm{cm})$ & Lab. No. & Age $14 \mathrm{C}(\mathrm{BP})$ & Calibrated age range $95 \%(\mathrm{BP})$ & Calendar age \\
\hline 1 & 330 & GdA-2979 & $830 \pm 25$ & $785(95.4 \%) 689$ & 1116-1261 A.D. \\
\hline 2 & 370 & GdA-2980 & $1090 \pm 25$ & $\begin{array}{c}1058(92.6 \%) 953 \\
947(2.8 \%) 939\end{array}$ & 892-1011 A.D. \\
\hline 3 & 410 & GdA-2981 & $1275 \pm 25$ & $\begin{array}{l}1284(94.6 \%) 1171 \\
1155(0.8 \%) 1149\end{array}$ & 666-801 A.D. \\
\hline 4 & 500 & GdA-2982 & $1610 \pm 25$ & $1546(95.4 \%) 1415$ & 404-535 A.D. \\
\hline 5 & 640 & GdA-2983 & $2470 \pm 25$ & $\begin{array}{l}2713(35.8 \%) 2629 \\
2623(55.2 \%) 2446 \\
2410(1.5 \%) 2397 \\
2392(2.8 \%) 2369\end{array}$ & 763-419 B.C. \\
\hline 6 & 710 & GdA-2984 & $2700 \pm 25$ & $2850(95.4 \%) 2757$ & 900-807 B.C. \\
\hline 7 & 800 & GdA-2985 & $3030 \pm 25$ & $3343(95.4 \%) 3161$ & 1393-1211 B.C. \\
\hline
\end{tabular}




\section{Pollen analysis}

Samples for palynological analyses $\left(1 \mathrm{~cm}^{3}\right)$ were collected usually at $5-10 \mathrm{~cm}$ intervals; only in the bottom part of the section $(900-1080 \mathrm{~cm})$ they were collected every $20 \mathrm{~cm}$. Samples were prepared using the standard procedure of Erdtman's acetolysis (Berglund and Ralska-Jasiewiczowa, 1986). According to degree of contamination by mineral fraction, samples were treated with a heavy liquid $\left(\mathrm{CdI}_{2}+\mathrm{KI}\right)$. Lycopodium tablets were added to each sample to enable quantitative analysis of microfossil concentrations (Stockmarr, 1971).

Pollen analysis was carried out with the Olympus BX43 light microscope with magnification of $600 \times$; a larger magnification was used to identify problematic and small palynomorphs. For taxonomical identification pollen keys (e.g. Beug, 2004) and a reference collection of modern pollen slides were used.

More than 1000 terrestrial pollen grains were counted and identified in each sample.

Calculations and presentation of palynological data in a simplified percentage pollen diagram were performed with POLPAL for Windows software (Nalepka and Walanus, 2003). AP+NAP sum was used for percentage calculations. The diagram was divided into local pollen assemblage zones (L PAZ) with Constrained Cluster Analysis (CONISS). To discuss interaction of anthropogenic and natural influences, the diagram was constructed with groups of taxa established by Behre (1981), with modification suggested by Berglund and Ralska-Jasiewiczowa (1986) and Veski (1998). Pollen curves of herbs were grouped into three categories: (1) cultivated crops, (2) weeds and ruderals, and (3) grassland and ecologically undefined plants.

\section{RESULTS}

\section{Chronology}

${ }^{14} \mathrm{C}$ and ${ }^{210} \mathrm{~Pb}$ dates were used for construction of the age-depth model for the analysed section (Fig. 2). This model was built by means of a polynomial 2nd degree curve fitting in the POLPAL program (Nalepka and Walanus, 2003; Walanus and Nalepka, 2004) and resulted in drawing the optimal depth-age curve on the basis of calibrated radiocarbon dates.

\section{Palynological data}

Palynological analysis was performed for 128 samples from the upper part of the section. Four local pollen assemblage zones (L PAZ) were distinguished (Fig. 3, Table 2).

\section{INTERPRETATION AND DISCUSSION}

\section{Early and middle Subboreal (3600-1850 cal. years BC) Quercus-Corylus L PAZ, depth: 1080-870 cm}

A vicinity of Lake Salęt was densely forested by multispecies deciduous woodland. Oak was the dominant tree in the older part of this period, but it gradually declined in fa-

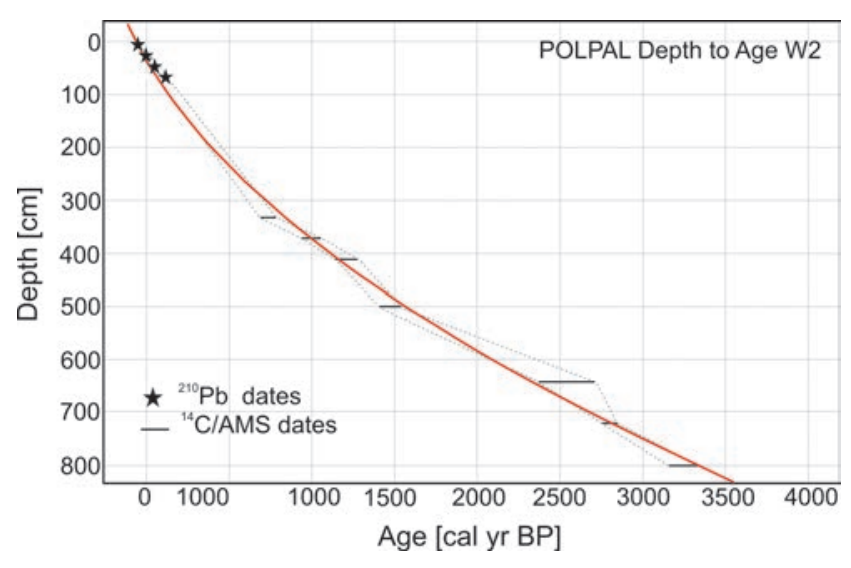

Fig. 2. Age-depth model of the Lake Salęt profile based on AMS ${ }^{14} \mathrm{C}$ and ${ }^{210} \mathrm{~Pb}$ dates.

vour of the increasing role of birch. Oak was a component of several communities, especially with hazel and pine. Due to its high ecological tolerance, oak developed in diverse habitats, from poor (Quercus petraea) to very rich (Quercus robur) (Szymański, 2006). From 3567 to 3399 cal. years BC, oak was the most important component of mixed and multispecies deciduous forests in the surroundings of Lake Salęt. According to Ralska-Jasiewiczowa et al. (2003), there are no close analogues to contemporary communities dominated by oak and hazel. They were formed in response to cyclic occupation and exploitation of the land by the Neolithic people. A rising pollen curve of Corylus avellana was probably due to slight opening of woodlands, which favoured intensive development of their understory. However, this process could have been also induced by drier climate conditions (low water level in lakes and dry phase in peat bogs) between 4050 and 3650 cal. years BP (Żurek and Pazdur, 1999), and its great potential for vegetation survival (Tallantire, 2002). In the pollen spectra from the Lake Salęt profile, Viscum album has been recorded in that time. In the neighbourhood of the studied area presence of this continental species has been also noted (Wacnik, 2009a) and it strongly suggested warm summers, with average temperature of the warmest month above $15.5^{\circ} \mathrm{C}$ (Iversen, 1944).

A distinct breakdown in the elm curve was noted in the Lake Salęt region between 2887 and 2563 cal. years BC (Fig. 3). A similar process occurred also in the Gostynin Lake District, where it was dated to $2850-2750$ cal. years BC (Wacnik et al., 2012b) and the increasing role of hazel was observed in the following centuries. The same pattern was noted in the surroundings of Lake Salęt, where beyond hazel, increased significance of pine and birch was recorded. Simultaneously with changes in forest composition, different open anthropogenic communities with ruderal, weed and grassland taxa developed, and in the youngest part of this period cereals have also appeared in pollen spectrum (palynological human phase 1).

The problem of decline of Ulmus in the Holocene has been intensively discussed during the last decades. Different hypotheses were proposed, e.g. climate change, human impact and finally, spreading of the so-called "Dutch" elm disease caused by an ascomycete fungus (Ceratocystis ulmi), and carried over by bark beetles Scotylus (e.g. Rackham, 


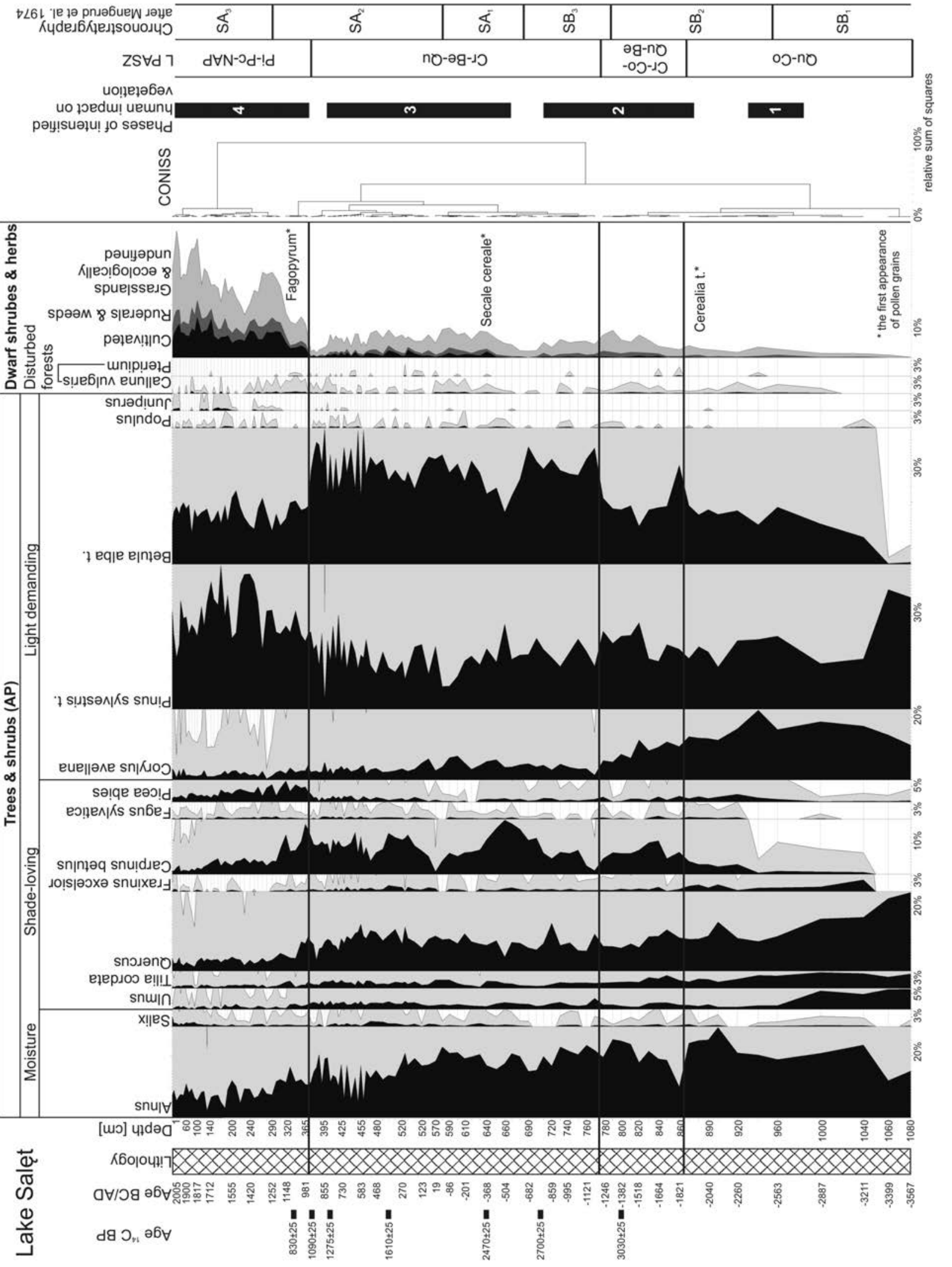


Table 2

Lake Salęt - description of local pollen assemblage zones (L PAZ)

\begin{tabular}{|c|c|}
\hline $\begin{array}{l}\text { Name of L PAZ } \\
\text { Depth [cm] and age [cal. } \\
\text { years] of pollen samples }\end{array}$ & Description \\
\hline $\begin{array}{l}\text { Pinus-Picea-NAP } \\
0-365 \mathrm{~cm} \\
2005-981 \mathrm{AD}\end{array}$ & $\begin{array}{l}\text { Domination of Pinus sylvestris t. (21-47\%); relatively high frequency of Picea abies (to 7\%); gradual decrease of Alnus } \\
\text { (to } 7-8 \% \text { ), Quercus (to ca. 2-3\%) and Carpinus betulus (to ca. 1\%); rather low values of Betula alba t. (below } 23 \% \text { ); low } \\
\text { frequency of Corylus avellana (to 3,5\%), Ulmus (to 1,8\%), Tilia cordata (to 2,4\%), Fraxinus excelsior (to } 0,8 \% \text { ), Salix (to } \\
1,3 \% \text { ) and Fagus sylvatica (to } 0,9 \% \text { ); relatively frequent Juniperus communis; sharp increase of NAP from } 7 \% \text { to } 16 \% \text {, } \\
\text { and then to } 48 \% \text { - highest amount of human indicators in the whole diagram (cultivated plants to } 16 \% \text {; ruderals and weeds } \\
\text { to } 8 \% \text { ). }\end{array}$ \\
\hline $\begin{array}{l}\text { Carpinus-Betula-Quercus } \\
370-770 \mathrm{~cm} \\
960 \mathrm{AD}-1183 \mathrm{BC}\end{array}$ & $\begin{array}{l}\text { Upper boundary: rapid fall of Betula alba t. below 18\%; rise of Pinus sylvestris t. above } 20 \% \text { and Picea abies to ca. } 5 \% \text {. } \\
\text { Absolute domination of Betula alba t. (20-44\%); high triple culmination of Carpinus betulus }(18 \%, 12 \% \text { and } 12 \% \text { ); still } \\
\text { high values of Quercus (8-14\%); strong fluctuations of Pinus sylvestris t. (8-30\%); low proportion of Ulmus (ca. } 2 \% \text { ), } \\
\text { Tilia cordata (ca. } 3 \% \text { ), Fraxinus excelsior (ca. 1\%), Salix (to } 1.5 \%) \text { and Fagus sylvatica (below } 1 \% \text { ); gradual decrease of } \\
\text { Alnus from } 20-24 \% \text { to 5-11\%; increase of herbaceous plants to } 12 \% \text { (cultivated plants up to 3\%; ruderals and weeds up to } \\
2 \% \text { ). }\end{array}$ \\
\hline $\begin{array}{l}\text { Carpinus-Corylus-Quercus- } \\
\text { Betula } \\
780-860 \mathrm{~cm} \\
1246-1821 \mathrm{BC}\end{array}$ & $\begin{array}{l}\text { Upper boundary: rapid rise of Betula alba t. above } 35 \% \text { and fall of Corylus avellana. } \\
\text { Rapid increase of Alnus (from } 10 \% \text { to } 23 \%) \text {; decrease of Quercus to } 8 \% \text { and Corylus avellana to } 6 \% \text {; low percentages of } \\
\text { Ulmus }(1-2 \% \text { and Tilia cordata }(2-4 \%) \text {; the first culmination of Carpinus }(10 \%) \text {; relatively low values of Pinus sylvestris } \\
\text { t. }(15-28 \%) \text { and Betula alba t. }(18-32 \%) \text {; rise of herbaceous plants to ca. } 10 \% \text { with clear increase of human indicators. }\end{array}$ \\
\hline $\begin{array}{l}\text { Quercus-Corylus } \\
870-1080 \mathrm{~cm} \\
1894-3567 \mathrm{BC}\end{array}$ & $\begin{array}{l}\text { Upper boundary: rise of Carpinus betulus to ca. } 7 \% \text {. } \\
\text { Relatively high frequency of Alnus to ca. 22-29\%; culminations of Quercus (26\%) and Pinus sylvestris t. (38\%) in the bot- } \\
\text { tom part of the zone, and then their gradual decline; low frequency of Ulmus to ca. } 1 \% \text { at the depth } 960 \mathrm{~cm} \text { (ca. } 2563 \mathrm{BC} \text { ); } \\
\text { almost constant Tilia cordata curve (ca. 5\%); fluctuations of Corylus avellana around } 20 \% \text {; gradual rise of Carpinus } \\
\text { betulus in the younger part of the zone; systematic increase of herbaceous plants (NAP) to ca. 5\% corresponding with ris- } \\
\text { ing values of Betula alba t. up to } 19 \% \text {. }\end{array}$ \\
\hline
\end{tabular}

1980). Elm reduction corresponds quite logically with such pathogenic hypothesis and it is not very concordant with migration routes of successive Neolithic cultures. However, it seems convincing (Girling and Greig, 1985; Birks, 1986, Ralska-Jasiewiczowa and van Geel, 1998; Peglar, 1993; Innes et al., 2010) that Neolithic people took advantage of elm disease to clear deciduous woods growing on more fertile soils. Pattern of distribution of Ulmus on Polish isopollen maps indicates that its decline has been more differentiated in time and space than previously accepted (Ralska-Jasiewiczowa et al., 2003). For instance, in the Bieszczady Mountains elm occurs around $4400-4200{ }^{14} \mathrm{C}$ years BP $(2450$ 2250 cal. years BC) only (Ralska-Jasiewiczowa, 1980) and in some lowland sites as early as $6000-5700{ }^{14} \mathrm{C}$ years BP (4050-3750 cal. years BC) (Latałowa, 1992). Decline of Ulmus is not a synchronous event in Estonia, as the dates range from 3800 to 3200 cal. years BC, likely due to human activity, connected with introduction of arable farming rather than by natural factors (Saarse and Veski, 2001). In the pollen diagram from Lake Salęt a very distinct elm decline is dated to the interval 2887-2563 cal. years BC (Fig. 3). Simultaneously with the decline of Ulmus, Picea abies developed in the vicinity of the studied site.

\section{Late Subboreal (1850-1200 cal. years BC)} Carpinus-Corylus-Quercus-Betula L PAZ, depth: $860-770 \mathrm{~cm}$

The most significant feature of this period was a very distinct spreading of hornbeam in stands of the Lake Salęt region. This process clearly coincided with decreased importance of hazel as well as lime, elm and oak. Changes in forest composition were most evidently a consequence of local anthropogenic pressure (a beginning of the palynological hu- man phase 2). Moreover, human activity resulting in clearing of some woodland areas, promoted spreading of hornbeam. Hornbeam has been well documented as a moderate pioneer species in recent years. It has rapidly colonized areas after fall of oak-hornbeam woods in the Białowieża Forest (Bernadzki et al., 1998).

In the younger part of this period a hornbeam area has decreased, and with high probability it could result from intensification of settlement at the transition of the Neolithic and Bronze Ages (Manasterski 2009). Cleared ground was used as pastures, meadows, fields and localities for settlements. Large areas of grasslands at that time indicated predominance of animal husbandry rather than cultivation.

Starting from ca. 1850 cal. years BC a gradual decrease in importance of hazel was noted. Very distinct decline of this species at that time is also recorded in numerous other pollen diagrams from Poland (e.g. Ralska-Jasiewiczowa et al., 2003), as well as in several sections from adjacent countries, mainly from Germany (e.g. Pott, 1986; Brauer et al., 2000; Kubitz, 2000). The onset of this process was determined to ca. $3400{ }^{14} \mathrm{C}$ years BP (ca. 1750 cal. years BC) in the Lake Gościąż (Ralska-Jasiewiczowa et al., 2003), and at ca. $3490{ }^{14} \mathrm{C}$ years BP (ca. 1860 cal. years BC) in lakes from the Eifel region in Germany (Brauer et al., 2000). At about 1700 cal. years BC forest transformations occurred around the Puck Bay in northern Poland (Miotk-Szpiganowicz, 1997; Uścinowicz and Miotk-Szpiganowicz, 2003), and somewhat similarly, Carpinus betulus started to develop in forest at the expense of Corylus avellana in the Zuławy region in the Vistula River mouth (Zachowicz et al., 1982, Zachowicz and Kępińska, 1987). There are some hints of both a thermal oscillation towards a cooling (Zolitschka, 1992) and an increase (although oscillating) in climate humidity (RalskaJasiewiczowa and Starkel, 1988), which might be a probable 
reason for decline of hazel. Increasing climate humidity ca. 1700 cal. years BC has been reconstructed for northern Britain (Charman et al., 2006) and northern Norway (Vorren et al., 2007). From ca. 1500 cal. years BC a groundwater table rose in mires of North Ireland (Swindles et al., 2010) and in southern Finland (Väliranta et al., 2007).

A broad spectrum of data from Polish fluvial, lake and peatland environments indicated also an increase in humidity between 4400-4100 and 3500-2900 cal. years BP (2450 2150 and 1550-950 cal. years BC, respectively) (RalskaJasiewiczowa and Starkel, 1988; Żurek and Pazdur, 1999; Starkel et al., 2006; Pawłowski et al., 2012). This part of the Subboreal chronozone was considered by Starkel (1990) and Starkel et al. (2006) to have been a wet period, characterized by more frequent rainy seasons. In the Polish isopollen map for $4000 \pm 100{ }^{14} \mathrm{C}$ years BP (ca. 2050 cal. years BC) MiotkSzpiganowicz et al. (2004) indicated that nearly the whole area of Poland was occupied by Corylus avellana pollen contents of 10-15\% (western, central and northern Poland, Carpathians Mountains and Roztocze). The values over 15\% occurred in the peri-Baltic area only and below $10 \%$ in the eastern part of the country up to the Podlasie border and the Carpathian Foredeep in the Małopolska Upland. The later decreased to below 5\% proceeded from SE-E across the whole country and the mentioned authors assumed that there were other reasons than a continental climate. It can be concluded that development of the Early Bronze Age cultures, practicing rather primitive arable agriculture but broadly dependent on cattle grazing (Manasterski 2009) may have contributed to shrinkage of hazel distribution.

In the middle of this period (ca. 1500 cal. years BC) areas with lime and temporarily, also the areas with elm have declined. The elm decline ca. 1700 years BC was also recorded in sections from the Lakes Miłkowskie and Wojnowo (Wacnik et al., 2012a). If these changes are accepted to have resulted from human activity, then increased pollen production of Corylus avellana can be explained by opening of the previously densely shaded deciduous forest by cutting of elm and lime branches for cattle fodder. Patches of open habitats began to spread in the area.

\section{Late Subboreal and early Subatlantic (1200 cal. years BC-1000 AD) \\ Carpinus-Betula-Quercus L PAZ, depth: $760-370 \mathrm{~cm}$}

Deep changes in structure of a mixed deciduous forest took place at the very beginning of this period, indicated by rapid spreading of birch. Vegetation transformations were caused both by natural interglacial succession provoked by climate change and by human economic activity. The dominating role of birch and hornbeam made forest structure different from the previous one. Hornbeam formed presumably the highest canopy layer that casted shadows on all lower storeys of the forest. This eliminated hazel from phytocenosis and limited its occurrence, probably to forest peripheries only. Hornbeam, due to its high ability to form suckers from trunk or stumps, could be the main element of regenerated forest, quickly occupying all larger clearings (Wacnik et al., 2012b). Maximum hornbeam expansion occurred about
500 cal. years BC (Fig. 3), just after the Lusatian culture settlement, which was the most widespread prehistoric culture in Poland, characterized by very high density of population (Godłowski and Kozłowski, 1979). A decline of this culture is reflected in a pollen diagram from Lake Salęt as the temporary regeneration of forest communities, first of pioneer birch woods and then of deciduous forest with dominant hornbeam. The following period of woodland reduction, with areas deforested or thinned by a man became overgrown by various anthropogenic open communities and by a heliophilous birch forest. The second, less intensive hornbeam expansion started from ca. 200 AD. A history of hornbeam in the Holocene in Central Europe was strictly connected with human activity (see Ralska-Jasiewiczowa, 1964; RalskaJasiewiczowa et al., 2004). This species was particularly devastated in periods with intensive settlement due to fertility of the occupied habitats. On the other hand, periods with reduced anthropogenic pressure allowed partial regeneration of forest communities with hornbeam, because of its great regenerative abilities.

Large areas in the vicinity of Lake Salęt were still occupied by oak. Birch forest played a significant role in the landscape, being probably secondary semi-natural communities which were formed in habitats transformed by exploitation during earlier settlement stages. An expansion of birch was also the most characteristic feature of this period in other parts of the Masurian Lake District. For example, this process was evident in pollen spectra from Lake Mikołajskie (Ralska-Jasiewiczowa, 1966), Woryty (Pawlikowski et al., 1982), Lake Dgał Wielki (Filbrandt-Czaja, 2000) and Lakes Miłkowskie, Łazduny and Wojnowo (Wacnik et al., 2012a). Similar development of communities with dominant birch was recorded in more or less the same time in diagrams from other parts of Poland, for instance from the Biebrza River Valley (Balwierz and Żurek, 1987), Suwałki Lake District (Lake Kluczysko - Wacnik, pers. comments), central Poland (Bińka et al., 1991), Gostynin Lake District (Wacnik et al., 2011; Wacnik et al., 2012b) and from Wielkopolska (Tobolski and Okuniewska-Nowaczyk, 1989). In the vicinity of Lake Salęt there were also pine and different mixed forests with pine-oak and pine-birch.

Alder grew on wetland habitats in the surroundings of the lake and in outskirts of rivers valleys. A relatively small area was occupied by elm, lime, ash and spruce. Other trees were rare.

The rise in frequency of pollen indicators of grasslands, i.e. meadows and pastures (the palynological human phase 3 ) indicates that surroundings of Lake Salęt have been to some extent influenced by a man. Intensive agriculture and a broad extent of disturbed soil with high $\mathrm{NO}_{3}$ content were confirmed by widespread presence of weeds and ruderals. Open areas were used for cultivation as denoted by continuous presence of Cerealia t. pollen, regular occurrence of Secale cereale pollen, and sporadic appearance of Triticum t., Avena t., and Hordeum t. pollen (this is not shown in the pollen diagram). Rye, as a wind-pollinated crop, has higher pollen production and better dispersal possibilities than other cereals, and thus its frequencies must represent not only local cultivation but also a regional background (cf. Koff and Punning, 2002). It is also possible that fields at the edge of Lake Salęt 
and appearance of forest grazing indicators (e.g. Pteridium aquilinum) point to somewhat more cattle-rearing activity in the area. In thinned and grazed forests Juniperus communis and Calluna vulgaris occurred.

\section{Late Subatlantic (1000-2005 AD) \\ Pinus-Picea-NAP L PAZ, depth: $365-0 \mathrm{~cm}$}

The beginning of this period was characterized by rapid deforestation and by marked increase in human activity. Withdrawal of tree pollen must have been connected with forest clearing undertaken in order to enlarge the areas of cultivated fields or pastures and with timber exploitation, which is documented in archaeological and historical sources (e.g. Wróblewski et al., 2003; Nowakiewicz, 2006, 2010). From around $1000 \mathrm{AD}$ extension of human economic activity started to transform the natural environment in a process persistent and continued up to the present time. According to RalskaJasiewiczowa (2006) this generated an ostensible picture resembling the approaching end of the Holocene interglacial cycle: disappearance of a deciduous forest and first mass spreading of pine, followed by total deforestation and occupation of its territory by open vegetation. Low values of tree pollen and predominance of long-distance transported pine pollen demonstrated existence of large open areas, which in turn suggested progressive development of settlements.

At the beginning of this zone there was a period of increased Carpinus betulus pollen percentages, which was contemporaneous with slightly growing human economic activity. A great regeneration ability of hornbeam allowed for its fast expansion in forest until the early Middle Ages. Soon afterwards, ca. $1250 \mathrm{AD}$, the areas dominated by hornbeam shrank gradually. Almost total elimination of Carpinus betulus from forest stands was probably the effect of farming intensification and growing demand for fertile soils. Diminished significance of Carpinus betulus in a forest could have been also caused by many years' cattle grazing, a consequence of which was a formation of well-lit oak-pine forest (Faliński and Pawlaczyk, 1993).

An importance of oak was still significant initially (9811033 AD). This could have been caused by selective protection of this tree by a man in order to provide acorns, which could be stored for up to three years (Weckerly et al., 1989) and used as fodder for pigs, particularly in winter time. Acorns are a source of a high-energy food and nowadays, in some seasons of a year, they may constitute up to $50 \%$ of the diet of some wild animals. Oak leaves are also rich in proteins (Pekins and Mautz, 1988; Elowe and Dodge, 1989). It is possible that acorns were also consumed by people, just as was the case up to recently among the aborigines of North America. According to Pekins and Mautz (1988) acorn production could have increased significantly by selective fall of trees in a forest and by protection of mature specimens. A sudden breakdown in a role of Quercus ca. 940 AD, synchronous with Carpinus betulus decline and increase of Pinus sylvestris t., should be strictly connected with human activity. Ralska-Jasiewiczowa (1964) explained that oak and hornbeam were particularly devastated species in periods of intensive settlement on account of fertility of the occupied habitats. She concluded also that these trees had great ability to regenerate in a comparatively short time and to spread over certain territories as one of the main components of an oak-hornbeam forest.

Some open areas may have become overgrown by wood, in which Picea abies was an important element. Spruce expansion in the Lake Salęt region was dated to ca. $1000 \mathrm{AD}$, as has been observed in some other diagrams from the Masurian Lake District (e.g. Filbrandt-Czaja, 2000; Wacnik et al., 2012a). An increasing presence of Calluna vulgaris and Pteridium aquilinum, both of which favour poorer sandy soils, suggests openings in a dry pine forest and subsequent application of these plots for animal husbandry. Pinus sylvestris spread most probably on less fertile, sandy habitats, which were covered previously by a mixed coniferous forest. Current distribution of pine was also connected with human activities. Culminations of Pinus sylvestris t. pollen curve immediately after each deforestation were almost certainly due to transport of pine pollen from distant areas and were also an evidence for spreading of pine to habitats occupied formerly by an oak-hornbeam forest.

At the same time herbaceous vegetation attained greater significance. Pollen grains of cultivated plants occurred frequently. Hitherto unrecorded Fagopyrum pollen appeared also in pollen spectra from the Lake Salęt profile (1116 AD), indicating that buckwheat was probably cultivated. This is in agreement with other European data showing that buckwheat, which was native to Central Asia and was introduced to Europe by the Mongols, was cultivated from $12^{\text {th }}-14^{\text {th }}$ centuries onwards (Speranza et al., 2000; Latałowa et al., 2007; Stančikaitè et al., 2008), although the earliest Polish record, known from the town of Wolin, dated back to $9^{\text {th }}-10^{\text {th }}$ centuries (Alsleben, 1995). Fagopyrum is an insect-pollinated plant which produces a small quantity of pollen that is usually underrepresented in pollen spectra. Results of modern pollen monitoring indicated that buckwheat, wheat and barley pollen appeared in low percentages, even when fields were located at a small distance from the sampling place (Pidek, 2009). Field and ruderal weeds appeared in higher percentages.

\section{CONCLUSIONS}

Pollen analysis of the upper part of the sedimentary sequence from Lake Salęt allowed reconstruction of vegetation changes in the Mragowo Lake District during Sub-boreal and Subatlantic chronozones of the Holocene (from ca. 3600 cal. years BC).

In the early Subboreal chronozone (3700-2900/2600 cal. years BC) oak-pine forest developed, but mixed deciduous woodland with elm, lime and hazel still occurred.

Very distinct transformation of a forest coincided with transition between early and middle Subboreal chronozone (2900-2600 cal. years BC). This is indicated by definite breakdown of elm, preceded by gradual drop of oak and spread of birch, which started from ca. 3300 cal. years BC. Then, from ca. 2300 cal. years BC, development of hornbeam and temporary extension of spruce occurred. At that time the first clearing by human communities occurred.

In the late Subboreal chronozone gradual elimination of hazel (1800-1200 cal. years BC) was accompanied by ex- 
pansion of hornbeam and progressive development of birch. This process should be probably linked with human activity rather (the Lusatian culture) and not with a climate changecrop cultivation started from 1800-1700 cal. years BC.

From the end of the Subboreal to the middle Subatlantic chronozone (1200 cal. years BC-1000 AD) a maximum spreading of birch and hornbeam forest occurred. Two periods of hornbeam expansion were recorded from that time, at 700-400 cal. years BC and 200-1000 AD. From ca. 500 cal. years BC distinct spreading of anthropogenic communities (grasslands, cultivated fields, ruderal communities) has started.

Extensive woodland clearances and occurrence of vast areas inhabited by people and exploited by them economically and agriculturally started from ca. 1000 AD. The areas of all trees, with exception of pine and spruce, were at that time substantially reduced.

A palynological study considering archaeological and historical information, which will provide a more detailed reconstruction of human impact on vegetation in the surroundings of Lake Salęt, will be published in a separate paper.

\section{Acknowledgements}

The study was financed by the Polish Ministry of Science and Higher Education through the project no. NN 304280540.

\section{REFERENCES}

Alsleben, A., 1995. Nutzpflanzen aus dem mittelalterlichen Wolin. Zwei ausgewählte Gruppen: Getreide und Lein. Offa 52, 185217.

Balwierz, Z., Żurek, S., 1987. The Late Glacial and Holocene vegetational history and palaeohydrological changes at the Wizna site (Podlasie Lowland). Acta Palaeobotanica 27, 1, 121-136.

Behre, K.E., 1981. The interpretation of anthropogenic indicators in pollen diagrams. Pollen and Spores 23, 2, 225-245.

Berglund, B.E., Ralska-Jasiewiczowa, M., 1986. Pollen analysis. In Berglund, B.E. (ed.), Handbook of Holocene Palaeoecology and Palaeohydrology, 455-484. John Wiley \& Sons, Chichester-New York-Brisbane-Toronto-Singapore.

Bernadzki, E, Bolibok, L, Brzeziecki, B, Zajączkowski, J, Żybura, H., 1998. Compositional dynamics of natural forest in the Białowieża National Park, northeastern Poland. Journal of Vegetation Sciences 9, 229-238.

Beug, H.J., 2004. Leitfaden der Pollenbestimmung für Mitteleuropa und angrenzende Gebiete, Verlag Dr. Friedrich Pfeil, München.

Bińka, K., Cieśla, A., Łącka, B., Madeyska, T., Marciniak, B., Szeroczyńska, K., Więckowski, K., 1991. The development of Błędowo Lake (Central Poland) - a palaeoecological study. Studia Geologica Polonica 100, 1-83.

Birks, H.J.B., 1986. Late Quaternary biotic changes in terrestrial and lacustrine environments, with particular reference to north-west Europe. In: Berglund, B.E. (Ed.), Handbook of Holocene Palaeoecology and Palaeohydrology, 3-65. John Wiley \& Sons, Chichester-New York-Brisbane-Toronto-Singapore.

Brauer, A., Kubitz, B., Litt, T., Negendank, J.F.W., Zolitschka, B., 2000 . Precision of varve time scales as demonstrated by comparing two long annually laminated sediment profiles from lakes Holzmaar and Meerfelder Maar. Terra Nostra 6, 65-70.

Charman, D.J., Blundell, A., Chiverrell, R.C., Hendon, D., Langdon, P.G., 2006. Compilation of non-annually resolved Holo- cene proxy climate records: stacked Holocene peatland palaeo-water table reconstructions from northern Britain. Quaternary Science Reviews 25, 336-350.

Elowe, K.D., Dodge, W.E., 1989. Factors affecting black bear reproductive success and cub survival. Journal of Wildlife Management 53, 4, 962-968.

Faliński, J.B., Pawlaczyk, P., 1993. Zarys ekologii. In Bugała, W. (ed.), Grab zwyczajny Carpinus betulus L. Nasze drzewa leśne. Monografie popularnonaukowe 9, 157-263. Sorus, Poznań-Kórnik.

Filbrandt-Czaja, A., 2000. Vegetation changes in the surroundings of Lake Dgał Wielki in the light of pollen analysis. In: Kola, A. (Ed.), Studies in Lake Dwellings of West Baltic Barrow Culture, 89-99. UMK, Torun.

Gałka, M., Tobolski, K., Zawisza, E., Goslar, T., 2014. Postglacial history of vegetation, human activity and lake-level changes at Jezioro Linówek in northeast Poland, based on multi-proxy data. Vegetation History and Archaeobotany 23, 123-152.

Girling, M.A., Greig, J., 1985. A first fossil record for Scotylus scotylus (F.) (Elm bark beetle): its occurrence in elm decline deposits from London and the implications for Neolithic elm disease. Journal of Archaeological Science 12, 347-351.

Godłowski, K., Kozłowski, J.K., 1979. Ancient history at the Polish territory (original: Historia starożytna ziem polskich). Państwowe Wydawnictwo Naukowe, Warszawa.

Huntley, B., 1990. Studying global change: the contribution of Quaternary palynology. Palaeogeography, Palaeoclimatology, $\mathrm{Pa}-$ laeoecology 82, 53-61.

Innes, J. B., Blackford, J. J., Simmons, I. G., 2010. Woodland disturbance and possible land-use regimes during the Late Mesolithic in the English Uplands: pollen, charcoal and non-pollen palynomorph evidence from Bluewath Beck, North York Moors, UK. Vegetation History and Archaeobotany 19, 439452.

Iversen, J., 1944. Viscum, Hedera and Ilex as climate indicators. Geologiska Föreningens i Stockholm Förhandlingar 66, 463483.

Jańczak, J., 1999. Atlas Jezior Polski, 3. IMGW, Bogucki Wydawnictwo Naukowe, Poznań.

Karczewski, M., 2011. Archeologia środowiska zachodniobałtyjskiego kręgu kulturowego na pojezierzach. Bogucki Wydawnictwo Naukowe, Poznań-Białystok.

Karpińska-Kołaczek, M., Kołaczek, P., Stachowicz-Rybka, R., Obidowicz A. 2013. Palaeobotanical studies on Late Glacial and Holocene vegetation development and transformations of the 'Wielkie Błoto' mire near Gołdap (north-eastern Poland). Acta Palaeobotanica 53, 1, 53-67.

Koff, T., Punning, J.M., 2002. The last hundred years of land-use history in Estonia as inferred from pollen records. Annales Botanici Fennici 39, 213-224.

Kołaczek, P., Kupryjanowicz, M., Karpińska-Kołaczek, M., Szal, M., Winter, H., Danel W., Pochocka-Szwarc, K., StachowiczRybka, R., 2013. The Late Glacial and Holocene development of vegetation in the area of a fossil lake in the Skaliska Basin (north-eastern Poland) inferred from pollen analysis and radiocarbon dating. Acta Palaeobotanica 53, 1, 23-52.

Kubitz, B., 2000. Die Holozäne Vegetations- und Siedlungsgeschichte in der Westeifel am Beispiel eines hochauflösenden Pollendiagrammes aus dem Meerfelder Maar. Dissertationes Botanicae 339, J. Cramer, Stuttgart.

Kupryjanowicz, M., 2008. Badania palinologiczne w Polsce północno-wschodniej. In Madeyska, E., Wacnik, A. (eds.), Polska północno-wschodnia w holocenie. Przyroda-klimat-człowiek. Botanical Guidebooks 30, 77-95

Latałowa, M. 1992. Forest changes at the Mesolithic/Early Neolithic transition and in the Migration Period on Wolin island 
(NW Poland). Paläoklimaforschung 8, 139-155.

Lamentowicz, M., Obremska, M., Mitchell, E.A.D., 2008. Autogenic succession, land-use change, and climatic influences on the Holocene development of a kettle hole mire in Northern Poland. Review of Palaeobotany and Palynology 15,1-2,21-40.

Latałowa, M., Badura, M., Jarosińska, J., Święta-Musznicka, J., 2007. Useful plants in medieval and post-medieval archaeo-bo tanical material from the Hanseatic towns of Northern Poland (Kołobrzeg, Gdańsk and Elblag). In Karg, S. (Ed.), Medieval food traditions in Northern Europe, 39-72, Studies in Archaeology and History, 12. Nationalmuseet, Copenhagen.

Manasterski, D., 2009. Pojezierze Mazurskie u schyłku neolitu i na początku epoki brązu w świetle zespołów Ząbie-Szestno. Instytut Archeologii Uniwersytetu Warszawskiego, Warszawa.

Matuszkiewicz, J.M., 2008. Geobotanical regionalization of Poland (Regionalizacja geobotaniczna Polski). IGiPZ PAN, Warszawa, wydawnictwo on-line (Available on http://www. igipz.pan.pl/tl_files/igipz/ZGiK/opracowania/regiony_geobo taniczne/regiony_opracowanie.pdf).

Miotk-Szpiganowicz, G., 1997. Results of palynological investigations in the Rzucewo area. In Król, D. (ed.) The Built Environment of Coast Areas during the Stone Age: The Baltic SeaCoast Landscapes Seminar: Session 1, 153-162, Regional Centre for Studies and Preservation of Built Environment in Gdańsk, Gdańsk.

Miotk-Szpiganowicz, G., Zachowicz, J., Ralska-Jasiewiczowa, M., Nalepka, D., 2004. Corylus avellana L. - Hazel. In: RalskaJasiewiczowa M., Latałowa M., Wasylikowa K., Tobolski K., Madeyska E., Wright H.E. Jr., Turner Ch. (eds.), Late Glacial and Holocene history of vegetation in Poland based on iso- pollen maps, 79-87, W. Szafer Institute of Botany, Polish Academy of Sciences, Kraków.

Nalepka, D., Walanus, A., 2003. Data processing in pollen analysis. Acta Palaeobotanica 43, 1, 125-134.

Nowakiewicz, T., 2006. Galindia in the Viking Age-New Shape of the Culture. In Bertašius, M. (Ed.), Transformatio Mundi. The Transition from the Late Migration Period to the Early Viking Age in the East Baltic, 161-172, Kaunas University of Technology, Department of Philosophy and Cultural Science, Kaunas.

Nowakiewicz, T., 2010. Some remarks on settlement systems of Early Medieval Prussians. The case of northern Galindia. In Lund Hansen, U., Bitner-Wróblewska, A. (Eds) Worlds Apart? Contacts across the Baltic See in the Iron Age. Network Denmark-Poland, 2005-2008. Nordiske Fortidsminder, C 7, 487-504. Det Kongelige Nordiske Oldskriftselskab, Państwowe Muzeum Archeologiczne, Krbenhavn-Warszawa.

Okulicz, J., 1973. Pradzieje ziem pruskich od późnego paleolitu do VII w. n.e. Zakład Narodowy im. Ossolińskich, Wrocław.

Peglar, S.M., 1993. The Mid-Holocene Ulmus decline at Diss Mere, Norfolk, UK: a year-by-year pollen stratigraphy from annual laminations. The Holocene 3, 1, 1-13.

Pawlikowski, M., Ralska-Jasiewiczowa, M., Schönborn, W., Stupnicka, E., Szeroczyńska, K., 1982. Woryty near Gietrzwałd, Olsztyn Lake District, NE Poland - vegetational history and lake development during the last 12000 years. Acta Palaeobotanica $22,1,85-116$.

Pawłowski, D., Kloss, M., Obremska, M., Szymanowski, M., Żurek, S., 2012. Evolution of small valley mire in central Poland as a result of hydroclimatic oscillations. Geochronometria 39, $2,133-148$.

Pekins, P.J., Mautz, W.W., 1988. Digestibility and nutritional value of autumn diets of deer. Journal of Wildlife Management 52, 2, $328-332$.

Pidek, I.A., 2009. Palinologiczny zapis sukcesji wtórnej na Roztoczu Środkowym: In Hildebrandt-Radke, I., Jasiewicz, J.,
Lutyńska, M. (Eds), Zapis działalności człowieka w środowisku przyrodniczym. Środowisko i kultura 6, 127-128, Bogucki Wydawnictwo Naukowe, Poznań.

Pott, R., 1986. Der pollenanalytische Nachweis extensiver Waldbewirtschaftungen in den Haubergen des Siegerlandes. In Behre, K.E. (Ed.), Anthropogenic indicators in pollen diagrams, 125-134, Balkema, Rotterdam.

Prentice, I. C., 1988. Records of vegetation in time and space: the principles of pollen analysis. In Huntley B., Webb T. (Eds.), Vegetation History, 16-42, Kluwer Academic Publishers, Dordrecht.

Rackham, O., 1980. Ancient woodland, its history, vegetation and uses in England. Arnold, London.

Ralska-Jasiewiczowa, M., 1964. Correlation between the Holocene history of the Carpinus betulus and prehistoric settlement in North Poland. Acta Societatis Botanicorum Poloniae 33, 2, 461-468.

Ralska-Jasiewiczowa, M., 1966. Bottom sediments of the Mikołajki Lake (Masurian Lake District) in the light of palaeobotanical investigations. Acta Palaeobotanica 7, 2, 1-118.

Ralska-Jasiewiczowa, M., 1980. Late-Glacial and Holocene vegetation of the Bieszczady Mts. (Polish Eastern Carpathians). Państwowe Wydawnictwo Naukowe, Warszawa-Kraków.

Ralska-Jasiewiczowa, M., 2006. Some comments on the palynostratigraphy of the Holocene in Poland, based on isopollen maps. Studia Quaternaria 23, 29-35.

Ralska-Jasiewiczowa, M., Starkel, L. 1988. Record of the hydrological changes during the Holocene in the lake, mire and fluvial deposits of Poland. Folia Quaternaria 57, 91-127.

Ralska-Jasiewiczowa, M., van Geel, B., 1998. Human impact on the vegetation of the Lake Gościąż surroundings in prehistoric and early-historic times. In Goslar, T., Madeyska, T., Starkel, L. (Eds) Lake Gościąż, central Poland. A monographic study, 1, 267-293, W. Szafer Institute of Botany, Polish Academy of Sciences, Kraków.

Ralska-Jasiewiczowa, M., Nalepka, D., Goslar, T. 2003. Some problems of forest transformation at the transition to the oligocratic/Homo sapiens phase of the Holocene interglacial in northern lowlands of central Europe. Vegetation History and Archaeobotany 12, 233-247.

Ralska-Jasiewiczowa, M., Miotk-Szpiganowicz, G., Zachowicz, J., Latałowa, M., Nalepka, D. 2004. Carpinus betulus L. - Hornbeam. In: Ralska-Jasiewiczowa, M., Latałowa, M., Wasylikowa, K., Tobolski, K., Madeyska, E., Wrigh,t H.E. Jr., Turner, Ch. (Eds), Late Glacial and Holocene history of vegetation in Poland based on isopollen maps, 69-78, W. Szafer Institute of Botany, Polish Academy of Sciences. Kraków.

Saarse, L., Veski, S., 2001. Spread of broad-leaved trees in Estonia. Proceedings of the Estonian Academy of Sciences, Geology $50,1,51-65$.

Speranza, A., Henke, J., van Geel, B., Fanta, J., 2000. Late-Holocene human impact and peat development in the Černá Hora bog, Krkonoše Mountains, Czech Republic. The Holocene 10, $575-585$

Stančikait , M., Kisielien , D., Mažeika, J., Blaževičius, P., 2008. Environmental conditions and human interference during the 6th and 13th-15th centuries A.D. at Vilnius Lower Castle, east Lithuania. Vegetation History and Archaeobotany 17, 239250.

Starkel, L., 1990. Evolution of the Vistula river valley during the last 15,000 years, Geographical Studies 3. Special Issue 5, $1-220$.

Starkel, L., Soja, R., Michczyńska, D.J., 2006. Past hydrological events reflected in the Holocene history of Polish rivers. Catena 66, 1-2, 24-33.

Stasiak, J., 1967. Notes on the origin of Late-Glacial lacustrine de- 
posits in North-Eastern Poland. Biuletyn Peryglacjalny 16 , 247-256.

Stasiak, J., 1971. Holocen Polski Północno-Wschodniej. Rozprawy Uniwersytetu Warszawskiego. PWN, Warszawa.

Stockmarr, J., 1971, Tablets with spores used in absolute pollen analysis. Pollen Spores 13, 615-621.

Swindles, G.T., Blundell, A., Roe, H.M., Hall, V.A., 2010. A 4500-year proxy climate record from peatlands in the North of Ireland: the identiWcation of widespread summer 'drought phases'? Quaternary Science Reviews 29, 1577-1589.

Szymański, S., 2006. Praktyczne zastosowanie znajomości ekologicznych wymagań dębów. In Boratyński, A., Bugała, W. (Eds) Dęby (Quercus robur L. i Q. petraea (Matt.) Liebl.). Nasze drzewa leśne. Monografie popularnonaukowe, 564 577, Instytut Dendrologii PAN, Poznań-Kórnik.

Tallantire, P.A., 2002. The early-Holocene spread of hazel (Corylus avellana L.) in Europe north and west of the Alps: an ecological hypothesis. The Holocene 12, 81-96.

Tobolski, K., Okuniewska-Nowaczyk, I., 1989. Type region p-r: Poznań-Gniezno-Kujawy Lake District. Acta Palaeobotanica 29, 2, 77-80.

Uścinowicz, S., Miotk-Szpiganowicz, G., 2003. Holocene shoreline migration in the Puck Lagoon (Southern Baltic Sea) based on the Rzucewo Headland case study. Landform Analysis 4, $81-95$.

Väliranta, M., Korhola, A., Seppä, H., Tuittila, E.-S., SarmajaKorjonen, K., Laine, J., Alm, J. 2007. High-resolution reconstruction of wetness dynamics in a southern boreal raised bog, Finland, during the late Holocene: a quantitative approach. The Holocene 17, 1093-1107.

Veski, S, 1998. Vegetation history, human impact and palaeogeography of western Estonia. Pollen analytical studies of lake and bog sediments. Striae 38.

Vorren, K.D., Blaauw, M., Wastegard, S., van der Plicht, H., Jensen, C., 2007. High-resolution stratigraphy of the northernmost concentric raised bog in Europe: Sellevollmyra, Andrya, northern Norway. Boreas 36, 253-277.

Wacnik, A. 2009a. From foraging to farming in the Great Mazurian Lake District - palynological studies of Lake Miłkowskie sediments, North-East Poland. Vegetation History and Archaeo-b otany $18,187-203$.

Wacnik, A. 2009b. Galindowie i Krzyżacy - oddziaływania na lokalną rośliność w rejonie Miłek i Staświn (Kraina Wielkich Jezior Mazurskich, północno-wschodnia Polska). Wiado- mości Botaniczne 53, 1-2, 21-34.

Wacnik, A., Ralska-Jasiewiczowa, M., Madeyska, E., 2011. Late Glacial and Holocene history of vegetation in Gostynin area, central Poland. Acta Palaeobotanica 51, 2, 249-278.

Wacnik, A., Goslar T., Czernik J. 2012a. Vegetation changes caused by agricultural societies in the Great Mazurian Lake District. Acta Palaeobotanica 52, 1, 59-104.

Wacnik, A., Ralska-Jasiewiczowa, M., Madeyska, E., 2012b. The history of woodland communities in the Gostynin region. In Rybicka, M., Wacnik, A. (Eds.) The impact of prehistoric and Medieval societies on the natural environment of the Gostynin Lake District, central Poland, 128-148, Collectio Archaeologica Ressoviensis Tomus XIX, Fundacja Rzeszowskiego Ośrodka Archeologicznego, Instytut Archeologii Uniwersytetu Rzeszowskiego, Rzeszów.

Walanus, A., Nalepka, D. 2004. Integration of Late Glacial and Holocene pollen data from Poland. Annales Societatis Geologorum Poloniae 74, 3, 285-294.

Weckerly, F.W., Sugg, D.W., Semlitsch, R.D., 1989. Germination success of acorns (Quercus): insect predation and tannins. Canadian Journal of Forest Research 19, 811-815.

Woś, A., 1999. Klimat Polski. PWN, Warszawa.

Wróblewski, W., Nowakiewicz, T., Bogucki, M. 2003. Terra desolata. Wczesnośredniowieczna Galindia w świetle badań mikroregionu Jeziora Salęt. In Wróblewski, W. (Ed.) Studia Galindzkie 1, 157-180, Instytut Archeologii Uniwersytetu Warszawskiego, Warszawa.

Zachowicz, J., Przybyłowska-Lange, W., Nagler, J., 1982. The Late-Glacial and Holocene vegetational history of the Żuławy Region, N Poland. A biostratigraphic study of Lake Drużno sediments. Acta Palaeobotanica 12, 1, 141-161.

Zachowicz, J., Kępińska, U., 1987. The Paleoecological development of Lake Drużno (Vistula Deltoic Area). Acta Palaeobotanica 27, 1, 227-249.

Zolitschka, B., 1992. Climatic change evidence and lacustrine varves from maar lakes, Germany. Climate Dynamics 6, 229 232.

Żurek, S., Pazdur, A., 1999. Zapis zmian paleohydrologicznych w rozwoju torfowisk Polski. In Pazdur, A., Bluszcz, A., Stankowski, W., Starkel L. (Eds.) Geochronologia górnego czwartorzędu Polski w świetle datowania radiowęglowego i luminescencyjnego, 215-228, Instytut Fizyki Politechniki Śląskiej, Gliwice. 